B I O S C I E N C E

J O U R N A L

\title{
ACCELERATED AGING TEST IN THE DETERMINATION OF SAFFLOWER SEEDS VIGOR
}

Mirelle Vaz COELHO ${ }^{1}$ (D) Ingrid Maressa Hungria de LIMA E SILVA² (iD, Amalia Andreza Sousa SILVA ${ }^{3}$ (D), Rogério Borges de Oliveira PAZ ${ }^{4}$ iD, Diego Ismael ROCHA ${ }^{5}$ iD, Carla Gomes MACHADO ${ }^{3}$ iD, Givanildo Zildo da SILVA ${ }^{3}$

\footnotetext{
${ }^{1}$ Education Department of Minas Gerais, Uberaba, Minas Gerais, Brazil.

2 Postgraduate Program in Agricultural Sciences, Goiano Federal Institute of Education, Rio Verde, Goiás, Brazil.

3 Postgraduate Program in Agronomy, Federal University of Jataí, Jataí, Goiás, Brazil.

${ }^{4}$ Federal Institute of the Triângulo Mineiro, Uberaba, Minas Gerais, Brazil.

${ }^{5}$ Department of Agronomy, Federal University of Viçosa, Viçosa, Minas Gerais, Brazil.
}

\section{Corresponding author:}

Givanildo Zildo da Silva

Email: givanildozildo@gmail.com

How to cite: COELHO, M.V., et al. Accelerated aging test in the determination of safflower seeds vigor. Bioscience Journal. 2022, 38, e38003. https://doi.org/10.14393/BJ-v38n0a2022-54228

\begin{abstract}
In assessing the quality of seed lots, the vigor tests are complementary to the germination test and they identify differences in the degree of deterioration of the lots. For safflower, there is little information regarding these tests. In this way, the intention of this study was to adapt the accelerated aging test methodology to assess the physiological potential of safflower seeds (Carthamus tinctorius). For this purpose, 12 seed lots were evaluated for thousand-seed weight, germination, first germination count, seedling emergence test (emergence percentage, emergence speed index, relative emergence frequency and the initial, final and mean times) and accelerated aging. For the accelerated aging test, the traditional and saline methods were used. For this, the samples were conditioned in periods of $0,8,16,24,32$ and 48 hours at $42^{\circ} \mathrm{C}$. Afterwards, they were submitted to the germination test, with evaluation of normal seedlings on the 3rd day. The 12 lots were evaluated within each period, in independent experiments. The data were submitted to analysis of variance and the means were compared using the Scott-Knott clustering method at $5 \%$ probability. In the traditional accelerated aging test the periods of $16,24,32$ and 48 hours were more efficient in differentiating the lots in vigor levels, as they stratified the lots in three classes and the time of 8 hour classified the lots in two levels of vigor. In the accelerated saline aging method the time 32 hours were more efficient since it ranked seed lots at three levels of vigor and the periods of 8, 16 and 24 hour stratified the lots in two levels. In results obtained by the principal component analysis it was verified. The variables traditional accelerated aging for 24 and 32 hours correlated with emergence in the field. Therefore, the traditional accelerated aging test at $42{ }^{\circ} \mathrm{C}$ for 24 hours are promising for evaluating the physiological quality of safflower seeds.
\end{abstract}

Keywords: Carthamus tinctorius. Physiological quality. Stress test. Vigor test.

\section{Introduction}

The safflower (Carthamus tinctorius) is an annual oleaginous plant to the Asteraceae Family (Yao et al. 2018). Due to the several forms of utilization, it has high economic value and is cultivated as a commercial product in several countries (Bidgoly et al. 2018). This culture presents several important features, such as: tolerance to saline soils, high temperatures, water deficit and low humidity (Kizil et al. 2008; Bagheri and 
Sam-Dailiri 2011). The safflower plant has the capacity to withstand a wide temperature range $\left(-7\right.$ to $\left.40{ }^{\circ} \mathrm{C}\right)$, depending on its stage of development, and adapts to different soil types (Coronado 2010; Emongor 2010). Given this, it can be used as an alternative for crop rotation in different areas of Brazil (Anicesio et al. 2015).

In addition to being used as an ornamental plant, its grains have an oil content of 35 to $50 \%$ and is very widespread in the form of capsules in natura, seeking health benefits. It can also be used as edible and industrial; its flowers are used as a source of natural dyes for food and fabrics and its grains are used in the feeding of birds and bran in the feeding of ruminants. This plant can also be used as a medicinal plant (Galavi 2012; Singh and Nimbkar 2016; Soleymani 2019). Studies are carried out with various plants that have a significant oil content in the production of biodiesel, aiming at the profitability of this product (Gomes Filho et al. 2015).

Evaluating the physiological quality of seeds is fundamental for making decisions regarding their use, as propagating material and for the subsequent stages to which they will be submitted (Frandoloso et al. 2017). The quality of the seed is the set of genetic, physical, physiological and sanitary attributes that affect its ability to originate high productivity plants (Lopes et al. 2017). The physiological potential can be assessed through germination and vigor tests (Marcos Filho 2015). However, as the germination test is performed under ideal conditions, vigor tests are relevant to complement the evaluation of seed lot potential.

The physiological quality of a seed lot is not easily measurable, as only an individual evaluation is not sufficient to define the vigor of the seed lot (Marinho et al. 2019). Therefore, it is important to use more than one vigor test to complement the germination test when evaluating the potential of seed lots.

The accelerated aging test is one of the efficient methods for evaluation in several species and is included in quality control programs by seed producing companies, because in a few days, relatively safe information can be obtained about the potential for storage of lots and field seedlings emergence. This is because it simulates stress conditions, generating a high rate of respiration and consumption of reserves, accelerating metabolic processes that lead to deterioration (Marcos Filho 2016).

In this test, the seeds are subjected to high temperatures, in conditions of high relative humidity, for varying periods of time, and then subjected to the germination test. The accelerated aging is based on the fact that the rate of seed deterioration is increased considerably through exposure to very adverse levels of temperature and relative humidity (Machado et al. 2019). Under these conditions, seeds of lower quality deteriorate faster than the more vigorous ones, with reflexes on germination after the accelerated aging period (Marcos Filho 2015).

There are few studies that performed this test on safflower seeds: Girardi et al. (2013) evaluated three lots at 41 and $43{ }^{\circ} \mathrm{C}$ in times of $0,24,48,72$ and 96 hours; Khavari et al. (2009) performed the aging of five lots at $38^{\circ} \mathrm{C}$ for 72 hours; Godakahriz et al. (2012) studied only one lot at $40{ }^{\circ} \mathrm{C}$, for 0,4 and 6 days; Demir (2014) artificially aged three lots at 41,43 and $45^{\circ} \mathrm{C}$ for $24,48,72$ and 96 hours. Therefore, it is noted that all the studies in which the accelerated aging test was performed on safflower seeds, evaluated few lots, with a maximum of five. Kaya et al. (2019), however, performed the accelerated aging test in 34 lots of safflower seeds, but used very long conditioning periods, which were 48, 72, 96, 120 and 144 hours. Consequently, there is still no standardized methodology for evaluating the vigor of safflower seeds through this test.

Moreover, in Brazil, in the Rules for Seed Testing (Brasil 2009), there are no standardized vigor tests for any crop. In the International Rules (ISTA 2014) there is standardization for electrical conductivity testing for peas, beans and soybeans; accelerated aging testing for soybeans; controlled deterioration testing for Brassica spp. and emergence of primary corn roots. For safflower, there is no standardized test.

Thus, the aim was to adapt the accelerated aging test methodology to assess the physiological potential of safflower seeds (Carthamus tinctorius). For this purpose, the best exposure period for the classification into different vigor levels was verified.

\section{Material and Methods}

Twelve lots of safflower seeds from the S-351 cultivar were selected, which come from the 2017/2018 off-season crop produced at the School Farm of the Federal University of Goiás - Jataí Regional. These lots were sent to the Seed Analysis Laboratory of the Federal University of Goiás - Jataí Regional, where the experiments were conducted. 
According to the requirements of the Rules for Seed Testing - RAS (Brasil 2009), the samples were initially homogenized, using the soil divider, passing them three times through the device. They were divided until four sub-samples were obtained, which corresponded to the statistical repetitions of the experiments performed.

\section{Determination of the moisture content of the seeds}

It was determined by the oven method according to the methodology indicated by RAS (Brasil 2009). The seeds were evenly distributed in the container and placed in the oven at $105 \pm 3{ }^{\circ} \mathrm{C}$ for 24 hours, with the use of two sub-samples of $4.0 \mathrm{~g}$ for each lot.

\section{Thousand-seed weight}

Four replicates of 8 sub-samples of 1000 seeds per lot were used. The masses were determined in a precision scale of 0.0001g according to the instructions of the RAS (Brasil 2009).

\section{Germination test}

The eight replicates of 25 seeds were placed to germinate between two layers of paper (blotting paper) inside transparent plastic boxes $(11.0 \times 11.0 \times 3.5 \mathrm{~cm})$. The paper was moistened with a volume of water $(\mathrm{mL})$ equivalent to 2.5 times the mass of the dry paper (g) (Brasil 2009), with final count the seeds germinated at eight days, according to Gama et al. (2019).

In the germination chambers, after the installation of the tests, the transparent plastic boxes remained conditioned in closed plastic bags of $45 \times 35 \mathrm{~cm}$, to avoid dehydration (Coimbra et al. 2007).

\section{First germination count}

It was performed along with the germination test, with a three-day count, accounting for the number of normal seedlings, according to Gama et al. (2019).

\section{Emergence of field seedlings}

The field seedling emergence test was conducted in March/April of 2019. Four subsamples of 50 seeds per lot were sown in forrows of one meter long with four centimeters of depth, without irrigation.

The maximum, average and minimum temperatures and rainfall prevailing during the period of conducting the field seedling emergence test are shown in Figure 1.

The evaluations were carried out with the normal seedling count, being accounted when the cotyledons were found above soil level, daily after sowing until stabilization in each lot, when the percentage of seedling emergence in the field was calculated (Nakagawa 1994).

It was also evaluated:

- First emergence count: accounted for when $50 \%+1$ of the total seedlings for most lots emerged.

- Emergence Speed Index (ESI): calculated from the daily seedling count data emerged from the field seedling emergence test and determined according to the formula proposed by Maguire (1962):

$\mathrm{ESI}=\underline{\mathrm{G}}_{1}+\underline{\mathrm{G}}_{2}+\ldots+\underline{\mathrm{G}}_{\mathrm{n}}$ :

$\begin{array}{lll}N_{1} & N_{2} & N_{n}\end{array}$

$\mathrm{ESI}=$ Emergence Speed Index;

$\mathrm{G}_{1}, \mathrm{G}_{2}, \mathrm{G}_{\mathrm{n}}$ = number of normal seedlings computed in the first, second and last count, respectively;

$N_{1}, N_{2}, N_{n}=$ number of days of sowing in the first, second and last count, respectively. 


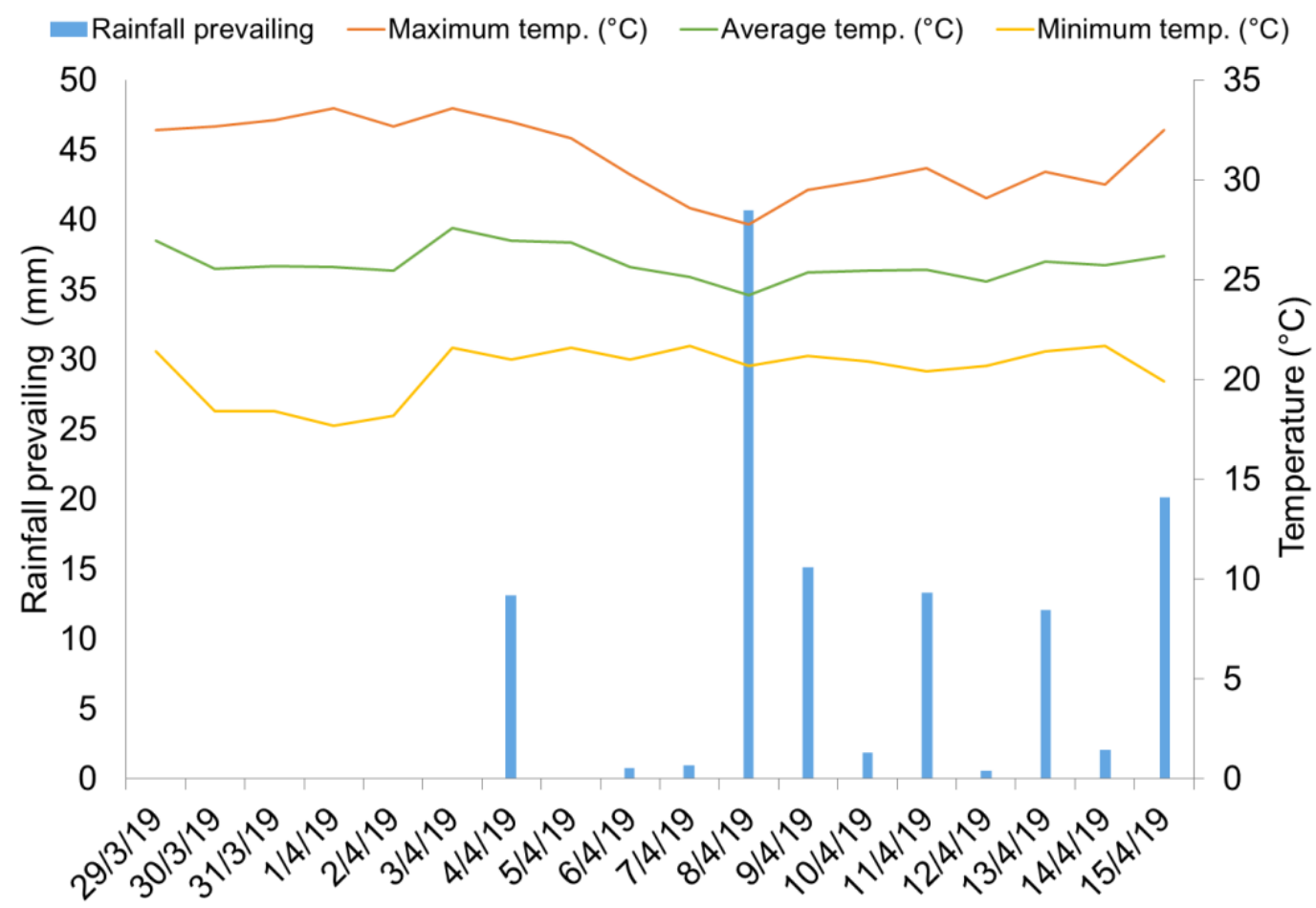

Figure 1. The maximum, average and minimum temperatures and rainfall prevailing during the period of conducting the field seedling emergence test.

- Initial, final, mean time and relative frequency of emergence of seedlings: from the daily emersed seedling count data of the field seedling emergence test, the initial, final, mean and relative frequency of emergence were determined. The initial time corresponds to the first emergence day after sowing and the final time to the last emergence day after sowing, for each lot. For the mean time and relative emergence frequency of emergence, the formulas described by Santana \& Ranal (2004) were used:

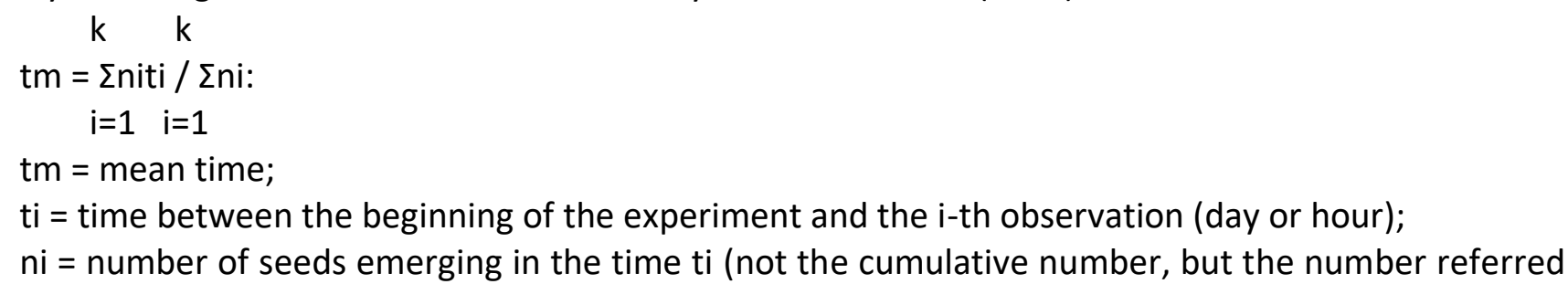
to the ith observation);

$\mathrm{k}=$ last seed emergence time.

$\mathrm{k}$

$\mathrm{fr}=\mathrm{ni} / \Sigma \mathrm{ni}:$

$\mathrm{i}=1$

$\mathrm{fr}=$ relative frequency of emergence;

$\mathrm{ni}=$ number of seeds emerging on day $\mathrm{i}$;

$\mathrm{k}=$ last day of observation.

- Traditional accelerated aging: Six independent experiments were conducted, in which the conditioning periods were represented: $0,8,16,24,32$ and 48 hours. Within each period, the 12 seed lots were evaluated in an entirely randomized design.

It was developed using 150 seeds for each lot that were distributed in a simple layer in a transparent plastic box $(11.0 \times 11.0 \times 3.5 \mathrm{~cm})$ adapted with an aluminum screen tray (Mcdonald Jr and Phaneendranath 1978). $40 \mathrm{~mL}$ of distilled water was added to the interior of the box. The containers were then placed in a germination chamber at $42^{\circ} \mathrm{C}$ and conditioned in the periods $0,8,16,24,32$ and 48 hours $40 \mathrm{~mL}$ of distilled water was added to the inside of the box. The containers were then placed in a germination chamber set at $42^{\circ} \mathrm{C}$ and packed in periods of $0,8,16,24,32$ and 48 hours. After these periods, 100 seeds were divided into 4 sub-samples of 25 seeds and the germination test was installed, as previously described, maintained at $25^{\circ} \mathrm{C}$, with the counting of the number of normal seedlings performed after 3 days of permanence of the 
seeds in the germinator. After the aging of the seeds, the degree of moisture was determined using 50 seeds that were subdivided into two sub-samples and placed in the oven at $105 \pm 3{ }^{\circ} \mathrm{C}$ for 24 hours, according to the Rules for Seed Analysis (Brasil 2009).

- Accelerated aging with saturated salt solution $(\mathrm{NaCl})$ : It was performed similar to the traditional method. However, $40 \mathrm{~mL}$ of saturated $\mathrm{NaCl}$ solution was added inside each plastic box to replace the distilled water. This solution was prepared in the proportion of $40 \mathrm{~g}$ of $\mathrm{NaCl}$ for $100 \mathrm{~mL}$ of water, establishing an environment with $76 \%$ relative humidity (Jianhua and McDonald 1996).

The data obtained in the initial characterization and in the tests of accelerated aging and cold (in which the 12 lots were evaluated within each period, in independent experiments) were submitted to analysis of variance at $5 \%$ probability by the $\mathrm{F}$ test and for comparison of the means the Scott-Knott method was used at $5 \%$ probability. Data were tested for normality and homogeneity and when necessary were transformed to $(x+0,5)^{0,5}$, the original data being shown in the table.

The principal component analysis was performed and processed in the $R$ program ( $R$ Core Team 2019). The eigenvectors between the original variables and the main components were calculated, being considered relevant with values above $0.5 /$ (eigenvalue) ${ }^{0,5}$ (Ovalles and Collins 1988). We considered significant eigenvectors greater than $0.128 ; 0.32$ and 0.35 for components 1,2 and 3 respectively.

\section{Results and Discussion}

The seeds of the 12 safflower lots showed moisture content between 5.23 and $6.18 \%$, the variation being less than one percentage point between the lots. This result is similar to the one found by Macedo (2018), who reports a variation in the moisture content of safflower seeds from 5.96 to $7.05 \%$. This variation is considered acceptable and desirable. Because, according to Marcos Filho (2016), differences of 1 to $2 \%$ between samples do not compromise the test results, since the uniformity of the initial seed moisture content is a key factor for the standardization of evaluations to be performed later.

In the characterization of the initial quality of the lots, significance was observed only for the variable dead seeds (Table 1).

Table 1. Summary of the analysis of variance of a thousand-seed weight (TSW), germination (G), abnormal seedlings (AS), dead seeds (DS) and germination first count (GFC), in a completely randomized design, emergence (E), emergence first count (EFC) and emergence speed index of seedlings in the field (ESI), initial time (IT), mean time (MT) and final time (FT) of the field emergence test, in a randomized block design, of twelve lots of safflower seeds.

\begin{tabular}{|c|c|c|c|c|c|c|c|c|c|c|c|c|c|}
\hline \multirow{3}{*}{ SV } & \multirow{3}{*}{$\mathrm{DL}$} & \multicolumn{12}{|c|}{ Middle square } \\
\hline & & \multicolumn{6}{|c|}{ Completely randomized design } & \multicolumn{6}{|c|}{ Randomized block design } \\
\hline & & TSW & $\mathrm{G}$ & AS & DS & GFC & GL & $E$ & EFC & ESI & IT & MT & FT \\
\hline Lots & 11 & $1.76 \mathrm{~ns}$ & $35.96 n s$ & $0.76 n s$ & $2.23 *$ & 97.79ns & 3 & $284.30 *$ & $817.77^{* *}$ & $1.14^{*}$ & $1.47^{* *}$ & $1.96 * *$ & $2.58 \mathrm{~ns}$ \\
\hline Residue & 36 & 0.74 & 29.00 & 0.80 & 1.04 & 84.33 & 11 & $43.17 n s$ & 70.60ns & $0.14 \mathrm{~ns}$ & $0.11 \mathrm{~ns}$ & $0.16 n s$ & $0.57 \mathrm{~ns}$ \\
\hline CV (\%) & - & 2.51 & 5.89 & 56.97 & 45.35 & 10.75 & 33 & 73.33 & 76.62 & 0.28 & 0.24 & 0.12 & 1.21 \\
\hline
\end{tabular}

${ }^{*}{ }^{* *},{ }^{\text {ns }}$ Significant at $5,1 \%$ and not significant by the $\mathrm{F}$ test, respectively. SV: Source of variation. DL: Degree of liberty. CV: Coefficient of variation.

The 12 lots of safflower seeds were grouped for the variable dead seeds in lots 1, 3, 4, and 7, with lower percentages, between 1 and 2\%; in the other lots, values were observed between 5 and $11 \%$. The Rules for Seed Testing define dead seeds as seeds that at the end of the test did not germinate, were not hard or dormant, and were generally softened and attacked by microorganisms (Brasil 2009). Marcos Filho (2016) emphasized that the death of the seed is caused by the deterioration that is a process determined by a series of physiological, physical, biochemical changes, starting from the physiological maturity, in progressive rhythm, in which culminates in the decline of the performance potential of the seed until its death.

For the other variables evaluated in the germination and emergence tests of field seedlings, no statistical differences were observed. Therefore, it is shown, in Figure 2, the bar of means and standard deviation of them. Carvalho and Nakagawa (2012) pointed out that the mass of the seeds is related to the number of reserves, being that seeds of the same species with greater mass present a superior number of 
tissues from reserves, thus conferring greater quality to these seeds. For this reason, usually lots with mass of a thousand similar seeds, present similar germination percentage, as found in this study.

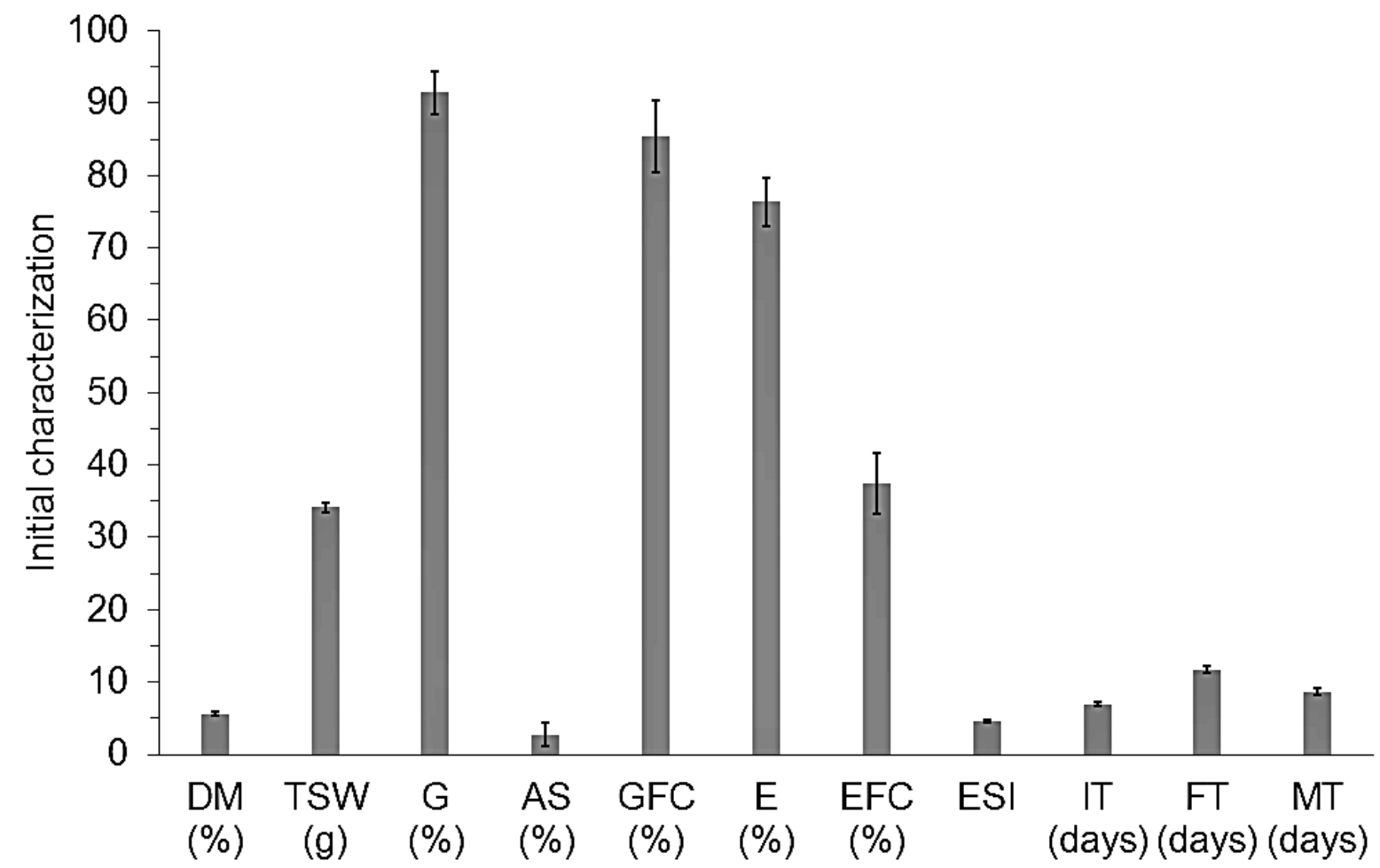

Figure 2. Initial characterization of the degree of moisture (DM), thousand-seed weight (TSW), germination

(G), abnormal seedlings (AS) and germination first count (GFC), in a completely randomized design, emergence (E), emergence first count (EFC) and emergence speed index of seedlings in the field (ESI), initial time (IT), mean time (MT) and final time (FT) of the field emergence test, in a randomized block design, of twelve lots of safflower seeds.

It is important that the evaluated samples, in addition to similar germination, are compatible with the standards established for marketing, because one of the objectives of vigor tests is to identify significant differences in the physiological quality of marketable lots (Marcos Filho 2015). The germination percentage maintained above $60 \%$, which is the minimum required for the production and marketing of seeds of species of large crops registered in the national register of cultivars not contemplated with a specific standard, as well as safflower (Brasil 2013).

Although the first count in this study of germination test and seedling emergence is considered an indication of vigor, it is known that during the process of seed deterioration, the reduction in germination speed is not among the first changes in the seed during deterioration, as related by Delouche and Baskin (1973). Therefore, it is a test that normally does not detect minor differences of vigor.

The field seedling emergence test allows the classification of lots according to their physiological potential, detecting differences not evidenced by the germination test. This test is considered an indicator parameter of the effectiveness of tests to assess the physiological potential of seed lots (Martins et al. 2014). However, there is not always a correlation between the results of vigor tests and those observed in the field, as found by Ávila et al. (2005) in canola seeds. Marcos Filho (2015) emphasized that the exclusive use of correlation analysis in evaluating the comparative efficiency of vigor tests may contribute to obtaining inconsistent information.

The mean emergence times, as well as the initial and final times, showed no difference, as found by Lenz et al. (2017) who assessed the germination of four different safflower genotypes at six sowing depths.

It was verified by the relative emergence frequency polygons (Figure 3 ) that the seedlings started to emerge between the 6th and 7th day after sowing, while the time for the last emergence ranged from 11 to 14 days. 
The distribution showed polymodal behavior, with more than one emergence peak, with the exception of lot 8 , demonstrating that there was no homogeneity in the emergence. This fact is explained because the germination process is not perfectly synchronized and is distributed over time.

Through the frequencies, it is possible to observe if over time the seeds germinate until they reach a maximum value and then decline (Santana and Ranal 2004). There was no displacement of the polygon in any of the cases because the mean times were similar. In general, the displacement of the polygonal line to the right or left of the mean time shows a delay in the germination process, as a result of the reduction in seed vigor (Berger 2014).

In Table 2 is a summary of the analysis of variance of the traditional and saline accelerated aging test in twelve lots of safflower seeds and six periods of traditional and saline aging, at a temperature of $42^{\circ} \mathrm{C}$. It is noted that in the traditional method, only the 0 -hour period was not significant. As for the saline aging, the periods of 0 and 48 hours did not differ between the lots.

It can be observed that there was a significant increase in the moisture content of the seeds after the traditional accelerated aging test (Table 3), as observed by Araújo et al. (2017) in leucene seeds. Marcos Filho (2016) states that the moisture content corresponds to the equilibrium point, which increases with the elevation of the relative humidity of the air and vice-versa. The seeds tend to reach hygroscopic equilibrium at higher water contents, as the relative humidity of the air increases (Costa et al. 2008).

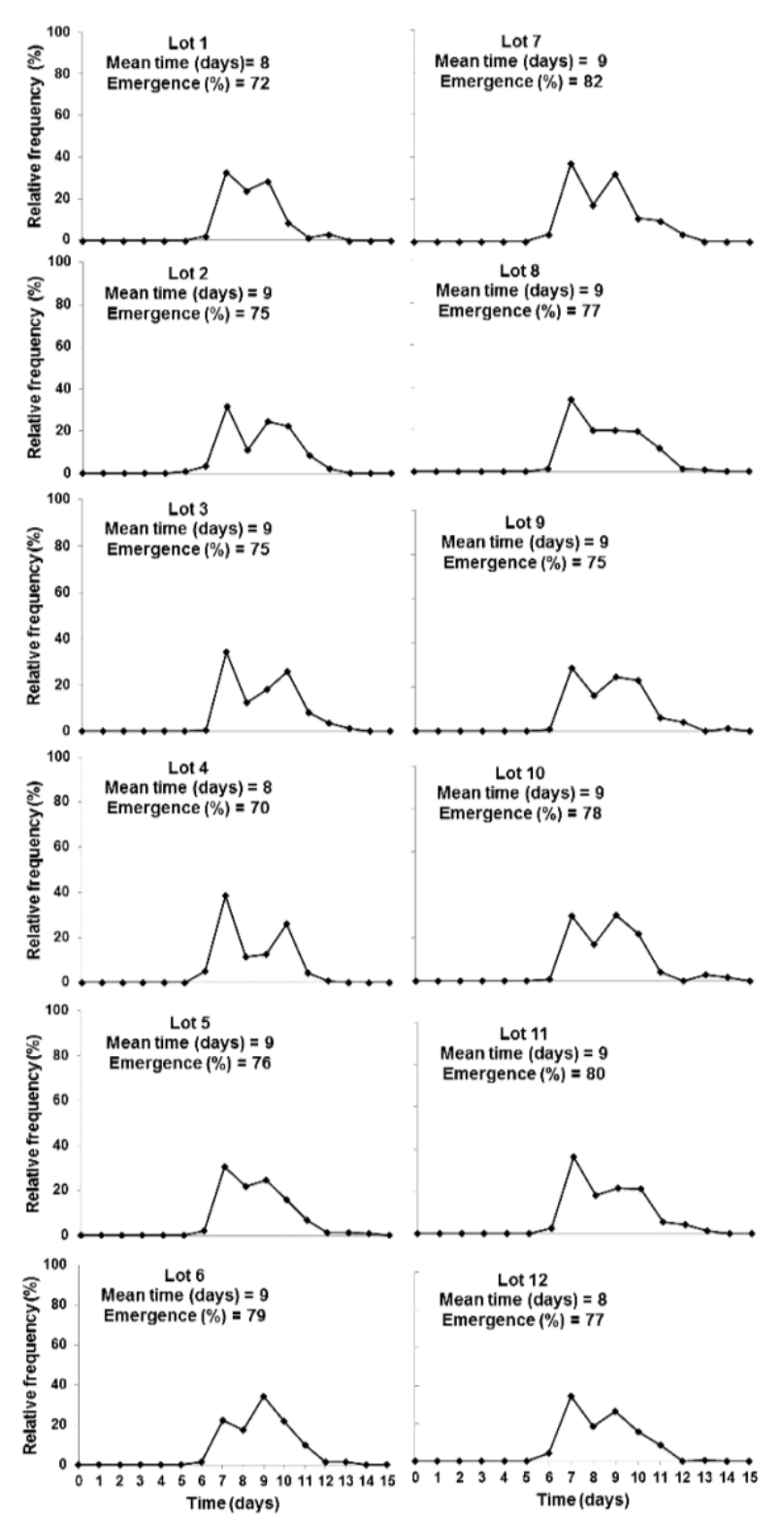

Figure 3. Distribution of the relative frequency of field seedling emergence in 12 lots of safflower seed. 
Table 2. Summary of the variance analysis of the traditional and saline accelerated aging test in twelve lots of safflower seeds after being submitted to the traditional and saline accelerated aging test in six periods.

\begin{tabular}{|c|c|c|c|c|c|c|c|}
\hline \multirow{3}{*}{ SV } & \multirow{3}{*}{$\mathrm{DL}$} & \multicolumn{6}{|c|}{ Middle square } \\
\hline & & \multicolumn{6}{|c|}{ Periods of traditional aging (hours) } \\
\hline & & 0 & 8 & 16 & 24 & 32 & 48 \\
\hline Lots & 11 & $97.79^{\text {ns }}$ & $122.42 * *$ & $269.75^{* *}$ & $445.88 * *$ & $253.96 * *$ & $738.34 * *$ \\
\hline Residue & 36 & 84.33 & 30.92 & 76.90 & 24.97 & 26.73 & 34.31 \\
\hline CV (\%) & - & 10.75 & 6.55 & 10.92 & 6.14 & 6.42 & 8.02 \\
\hline \multirow{2}{*}{ SV } & \multirow{2}{*}{$\mathrm{DL}$} & \multicolumn{6}{|c|}{ Periods of saline aging (hours) } \\
\hline & & 0 & 8 & 16 & 24 & 32 & 48 \\
\hline Lots & 11 & $97.79^{\text {ns }}$ & $96.38^{*}$ & $88.34 * *$ & $177.17^{* *}$ & $112.74 * *$ & $75.14^{\mathrm{ns}}$ \\
\hline Residue & 36 & 84.33 & 39.13 & 18.23 & 16.19 & 26.35 & 41.56 \\
\hline CV (\%) & - & 10.75 & 7.74 & 5.01 & 4.95 & 6.27 & 8.05 \\
\hline
\end{tabular}

**, ns Significant at $1 \%$ and not significant by the F test, respectively. SV: Source of variation. GL: Degree of liberty. CV: Coefficient of variation.

It was noted that seed moisture also increased by the accelerated aging method with saturated salt solution, but to a lesser extent than the traditional method (Table 3). These results are similar to those found by Frandoloso et al. (2017), Tunes et al. (2013) and Radke et al. (2016), who by performing the accelerated aging test on seeds of lettuce, parsley and coriander, respectively, also noted that the traditional method increases the moisture content higher than the saline method. Thus, it is possible to verify that the use of $\mathrm{NaCl}$ solution provided the reduction in water absorption by the seeds, as proposed by Jianhua and McDonald (1996). This is because the water is osmotically retained in the saline solution, so that the increased concentration of salts makes it less and less available (Ribeiro et al. 2001).

Table 3. Degree of moisture (\%) of the safflower seeds submitted to the traditional and saline accelerated aging test at $42{ }^{\circ} \mathrm{C}$ for $0,8,16,24,32$ and 48 hours.

\begin{tabular}{|c|c|c|c|c|c|c|c|c|c|c|c|c|}
\hline \multirow{2}{*}{ Lots } & \multicolumn{6}{|c|}{ Periods of traditional aging (hours) } & \multicolumn{6}{|c|}{ Periods of saline aging (hours) } \\
\hline & 0 & 8 & 16 & 24 & 32 & 48 & 0 & 8 & 16 & 24 & 32 & 48 \\
\hline 1 & 6.18 & 12.91 & 11.74 & 11.84 & 17.95 & 14.92 & 6.18 & 7.39 & 7.12 & 7.58 & 7.20 & 7.59 \\
\hline 2 & 5.94 & 12.65 & 14.35 & 13.89 & 17.24 & 17.78 & 5.94 & 6.81 & 6.81 & 7.85 & 7.28 & 7.34 \\
\hline 3 & 5.47 & 11.76 & 11.31 & 13.93 & 17.78 & 14.19 & 5.47 & 7.43 & 6.68 & 6.96 & 7.39 & 7.41 \\
\hline 4 & 5.57 & 12.28 & 13.15 & 11.15 & 18.53 & 14.26 & 5.57 & 7.68 & 7.16 & 7.53 & 7.02 & 7.48 \\
\hline 5 & 5.57 & 11.52 & 12.43 & 14.77 & 17.79 & 13.23 & 5.57 & 7.40 & 6.79 & 7.21 & 6.99 & 7.39 \\
\hline 6 & 5.79 & 11.80 & 12.35 & 13.44 & 17.81 & 16.15 & 5.79 & 7.59 & 6.99 & 7.50 & 7.55 & 7.45 \\
\hline 7 & 5.47 & 12.20 & 11.83 & 11.40 & 17.54 & 14.76 & 5.47 & 7.21 & 7.62 & 7.50 & 7.09 & 7.74 \\
\hline 8 & 5.55 & 12.36 & 11.35 & 13.31 & 17.19 & 17.28 & 5.55 & 7.82 & 7.32 & 7.67 & 7.39 & 7.50 \\
\hline 9 & 5.63 & 11.72 & 10.82 & 12.95 & 17.30 & 16.27 & 5.63 & 7.18 & 6.33 & 8.21 & 7.32 & 7.40 \\
\hline 10 & 5.62 & 11.44 & 12.83 & 14.70 & 17.40 & 14.31 & 5.62 & 7.74 & 7.04 & 7.54 & 6.76 & 7.48 \\
\hline 11 & 5.23 & 12.38 & 14.65 & 14.39 & 16.48 & 16.69 & 5.23 & 7.49 & 6.98 & 7.76 & 7.25 & 8.03 \\
\hline 12 & 5.69 & 12.84 & 13.82 & 12.15 & 17.74 & 16.07 & 5.69 & 7.28 & 6.73 & 7.21 & 7.12 & 7.52 \\
\hline
\end{tabular}

Marcos Filho (2016) recommends that the difference in the moisture content of the seeds after aging must be less than four percentage points. In this sense, it can be noted that the data of saline aging are more uniform, because the variation in water content was less than $4 \%$. In traditional aging, in the period of 48 hours, the seeds presented a higher variation than recommended.

The comparison of means referring to the germination percentage of twelve lots of safflower seeds (Table 4), in traditional accelerated aging, the time of 8 hours, ranked the lots in two levels of vigor. However, the periods of 16, 24, 32 and 48 hours of traditional accelerated aging stratified the lots into three classes, thus being more efficient in differentiating the lots into levels of vigor. Menezes et al. (2008) pointed out that the efficiency of this test is assessed by the difference in sensitivity presented by the seeds to aging. These results corroborate with those found by Girardi et al (2013) and Godakahriz et al. (2012) who also identified differences in the physiological potentials in safflower seed lots in different periods. However, these authors used long periods of exposure, being: 0, 24, 48, 72 and 96 hours and 0, 4 and 6 days, respectively. Marcos Filho (2015) emphasizes that the vigor test must be simple, fast, low cost, objective and reproducible. Therefore, the faster the test runs, the more efficient it will be. Rocha et al. (2015), who also 
differentiated lots of sunflower seeds at different levels of vigor through the accelerated aging test, corroborating with the results found in lettuce seeds (Barbosa et al. 2011) and parsley (Tunes et al. 2013).

With the increase of the temperature and longer time spent in aging conditions, the germination tends to be negatively affected (Flavio and Paula 2010). However, this information cannot be generalized, since in the present study, as found by Araújo et al. (2017) in leucene seeds, some lots increased the germination percentage with the expansion of the period of exposure to accelerated aging. This fact is explained due to the greater stress tolerance of these lots, thus giving them greater physiological potential.

In the accelerated saline aging method, the 8-, 16- and 24-hour times stratified the lots of safflower seeds in two levels of vigor. The 32-hour period, on the other hand since it ranked the safflower seed lots at three levels of vigor. Martins et al. (2018) also succeeded in stratifying amaranth seed lots at different vigor levels.

Table 4. Germination (\%) of the seeds of twelve safflower lots, after six conditioning periods $(0,8,16,32,24$ e 48 horas) at a temperature of $42^{\circ} \mathrm{C}$ for the traditional and saline accelerated aging test.

\begin{tabular}{|c|c|c|c|c|c|c|c|c|c|c|c|c|}
\hline \multirow{2}{*}{ Lots } & \multicolumn{6}{|c|}{ Periods of traditional aging (hours) } & \multicolumn{6}{|c|}{ Periods of saline aging (hours) } \\
\hline & 0 & 8 & 16 & 24 & 32 & 48 & 0 & 8 & 16 & 24 & 32 & 48 \\
\hline 1 & $94^{a}$ & $76^{b}$ & $72^{\mathrm{b}}$ & $79^{a}$ & $76^{b}$ & $68^{b}$ & $94^{\mathrm{a}}$ & $72^{b}$ & $87^{\mathrm{a}}$ & $75^{b}$ & $79^{b}$ & $79^{a}$ \\
\hline 2 & $77^{\mathrm{a}}$ & $84^{a}$ & $84^{\mathrm{a}}$ & $71^{\mathrm{b}}$ & $68^{c}$ & $88^{a}$ & $77^{\mathrm{a}}$ & $79^{b}$ & $78^{\mathrm{b}}$ & $88^{\mathrm{a}}$ & $81^{b}$ & $75^{\mathrm{a}}$ \\
\hline 3 & $91^{\mathrm{a}}$ & $87^{\mathrm{a}}$ & $88^{a}$ & $86^{a}$ & $83^{b}$ & $81^{\mathrm{a}}$ & $91^{\mathrm{a}}$ & $85^{a}$ & $93^{a}$ & $90^{\mathrm{a}}$ & $80^{\mathrm{b}}$ & $87^{a}$ \\
\hline 4 & $80^{\mathrm{a}}$ & $87^{a}$ & $88^{a}$ & $83^{a}$ & $80^{b}$ & $56^{c}$ & $80^{a}$ & $82^{a}$ & $87^{a}$ & $80^{b}$ & $88^{a}$ & $81^{a}$ \\
\hline 5 & $87^{a}$ & $91^{\mathrm{a}}$ & $87^{a}$ & $88^{a}$ & $83^{b}$ & $51^{c}$ & $87^{a}$ & $85^{a}$ & $81^{b}$ & $88^{a}$ & $71^{c}$ & $79^{a}$ \\
\hline 6 & $87^{a}$ & $91^{\mathrm{a}}$ & $60^{c}$ & $86^{a}$ & $83^{b}$ & $50^{c}$ & $87^{a}$ & $77^{b}$ & $80^{b}$ & $81^{b}$ & $75^{c}$ & $76^{a}$ \\
\hline 7 & $88^{a}$ & $88^{a}$ & $81^{a}$ & $86^{a}$ & $81^{b}$ & $85^{a}$ & $88^{a}$ & $88^{a}$ & $83^{b}$ & $79^{b}$ & $85^{a}$ & $79^{a}$ \\
\hline 8 & $82^{\mathrm{a}}$ & $80^{b}$ & $83^{a}$ & $88^{a}$ & $92^{\mathrm{a}}$ & $84^{a}$ & $82^{\mathrm{a}}$ & $81^{a}$ & $90^{\mathrm{a}}$ & $84^{a}$ & $86^{a}$ & $73^{a}$ \\
\hline 9 & $84^{a}$ & $91^{\mathrm{a}}$ & $81^{a}$ & $90^{\mathrm{a}}$ & $83^{b}$ & $79^{a}$ & $84^{a}$ & $86^{a}$ & $89^{a}$ & $89^{a}$ & $84^{a}$ & $85^{a}$ \\
\hline 10 & $82^{\mathrm{a}}$ & $77^{b}$ & $73^{b}$ & $86^{a}$ & $87^{a}$ & $77^{a}$ & $82^{a}$ & $74^{b}$ & $88^{a}$ & $76^{b}$ & $88^{a}$ & $84^{a}$ \\
\hline 11 & $83^{a}$ & $79^{b}$ & $81^{a}$ & $52^{c}$ & $64^{c}$ & $80^{a}$ & $83^{a}$ & $83^{a}$ & $85^{a}$ & $69^{b}$ & $85^{a}$ & $85^{a}$ \\
\hline 12 & $90^{\mathrm{a}}$ & $89^{a}$ & $85^{a}$ & $82^{a}$ & $88^{a}$ & $77^{a}$ & $90^{\mathrm{a}}$ & $79^{b}$ & $80^{b}$ & $76^{b}$ & $80^{b}$ & $78^{a}$ \\
\hline
\end{tabular}

Means followed by the same letter in the column do not differ by Scott-Knott test at 5\% probability.

Based on the results obtained by the principal component analysis (Table 5), it was verified the need for three components, since these effectively summarize the total sample variance and can be used to study the data set, since according to Hongyu et al. (2016) the eigenvalues of these components were higher than 1. The three main components accounted for $64.41 \%$ of the accumulated variation, on the breakdown of lots in relation to their quality, where CP1 accounted for $27.13 \%$, CP2 by $20.14 \%$ and CP3 by $17.14 \%$ of the data variation (Table 5).

Table 5. Matrix of eigenvectors and eigenvalues of principal components (PC) and evaluation of physiological quality of 12 safflower seeds lots.

\begin{tabular}{|c|c|c|c|c|}
\hline \multicolumn{2}{|c|}{ Variables } & PC 1 & PC 2 & PC 3 \\
\hline \multicolumn{2}{|c|}{ First germination count } & 0.18 & 0.43 & 0.22 \\
\hline \multicolumn{2}{|c|}{ Germination } & 0.12 & 0.42 & 0.25 \\
\hline \multicolumn{2}{|c|}{ Field seedling emergence } & 0.39 & 0.09 & 0.04 \\
\hline & 8 hours & 0.41 & -0.16 & -0.28 \\
\hline Aging & 16 hours & 0.08 & -0.44 & 0.10 \\
\hline \multirow[t]{3}{*}{ Traditional } & 24 hours & 0.49 & 0.07 & 0.14 \\
\hline & 32 hours & 0.42 & 0.11 & 0.22 \\
\hline & 8 hours & 0.24 & -0.43 & 0.02 \\
\hline \multirow{4}{*}{$\begin{array}{l}\text { Aging } \\
\text { Saline }\end{array}$} & 16 hours & 0.02 & -0.14 & 0.62 \\
\hline & 24 hours & 0.33 & 0.31 & -0.13 \\
\hline & 32 hours & -0.19 & 0.24 & 0.39 \\
\hline & 48 hours & -0.09 & -0.19 & 0.43 \\
\hline \multirow{2}{*}{\multicolumn{2}{|c|}{$\begin{array}{l}\text { Eigenvalues } \\
\text { Variance (\%) }\end{array}$}} & 3.26 & 2.42 & 2.06 \\
\hline & & 27.13 & 20.14 & 17.14 \\
\hline
\end{tabular}

Representative variables of the component based on the ratio module $0,5 /(\text { 国 })^{0,5}$, highlighted in bold (Ovalles and Collins 1988 ). 
The seedling emergence variables in the field, traditional accelerated aging for 8,24 and 32 hours, and saline for 24 hours had higher discriminatory power for the main component 1 . The variables traditional accelerated aging for 24 and 32 hours with interaction between themselves and correlated with emergence in the field since their vectors are in the same direction and forming sharp angles to each other (Figure 4). These tests are promising in the evaluation of safflower seeds, since lots 2 and 11 were similarly classified.

The variables first germination count, germination, traditional aging for 16 hours and saline for 8 hours presented discriminatory power for the main component 2 . The first two variables are correlated to each other, as the last two, according to the angles between their vectors (Figure 4). However, the aging variables, even presenting a discriminatory power for the main component 2 , they presented a negative sign, since, the highest percentage of seedlings obtained after aging, the lowest was the germination and first count variables. These variables would not be efficient to evaluate safflower seed quality.

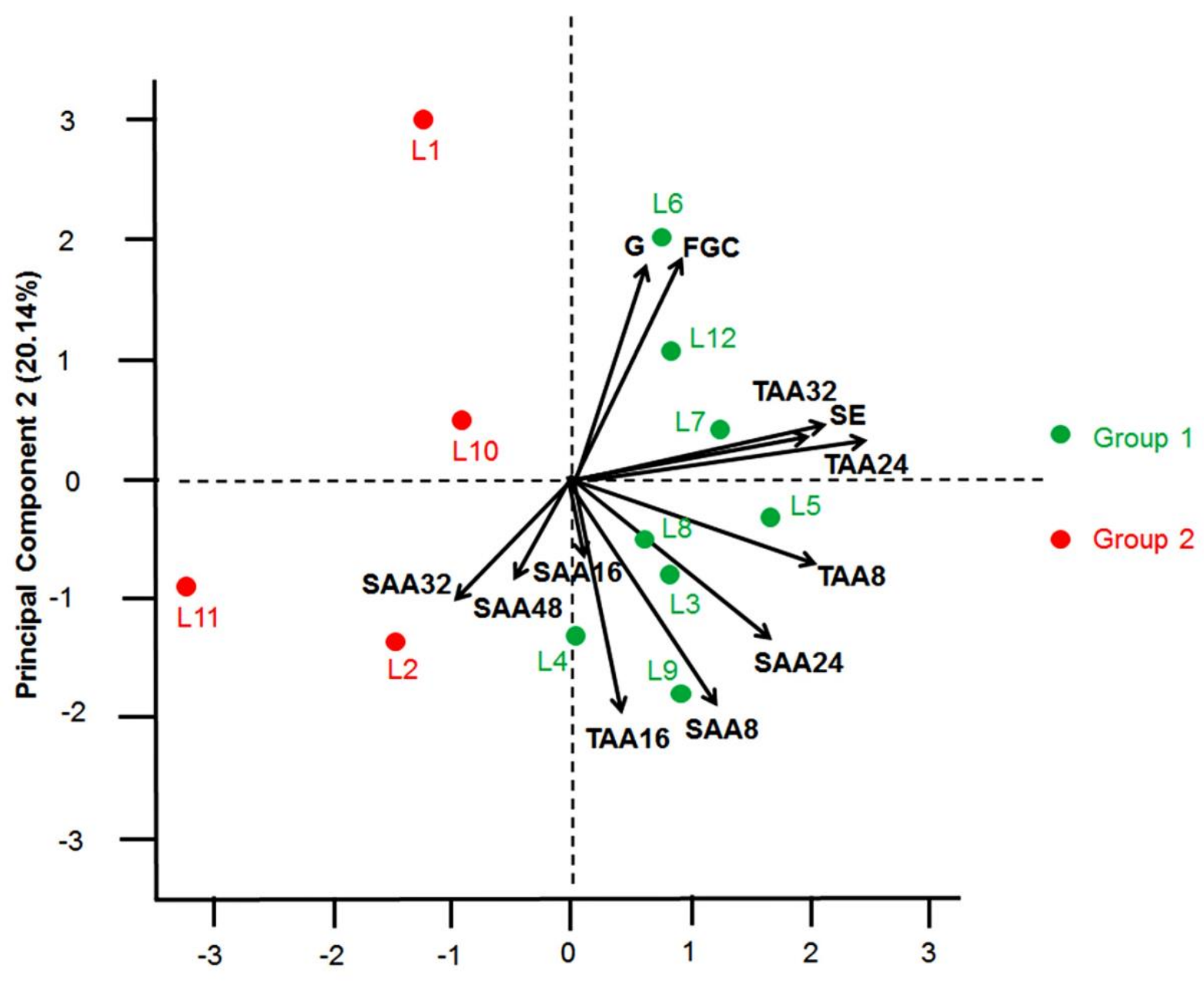

Principal Component 1 (27.13\%)

Figure 4. Scatter of eigenvectors along a circular plane and group formation obtained by principal component analysis according to the variables: first germination count (FGC), germination (G), seedling emergence (SE), traditional accelerated aging at 8, 16, 24 and 32 hours (TAA8, TAA16, TAA34 and TAA32, respectively) and saline at $8,16,24,32$ and 48 hours (SAA8, SAA16, SAA24, SAA 32 and SAA48, respectively) in the evaluation of 12 safflower seed lots.

For the main component 3 , the variables that had the greatest discriminatory power were the accelerated saline aging at 16, 32 and 48 hours (Table 5). As the number of components used increases, they have less cumulative variance. Therefore, the variables of these components would have less discriminatory power in the evaluation of safflower seed lots. 


\section{Conclusions}

The traditional accelerated aging test at $42{ }^{\circ} \mathrm{C}$ for 24 hours are promising for evaluating the physiological quality of safflower seeds. This result is satisfactory since the period used is shorter than the other research already carried out. Therefore, the test becomes more efficient in identifying different physiological potentials in safflower seed lots.

Authors' Contributions: COELHO, M.V.: conception and design, acquisition of data, analysis and interpretation of data, drafting the article; LIMA E SILVA, I.M.H.: acquisition of data, analysis and interpretation of data; SILVA, A.A.S.: acquisition of data, analysis and interpretation of data; PAZ, R.B.O.: acquisition of data, analysis and interpretation of data; ROCHA, D.I.: conception and design, analysis and interpretation of data, drafting the article; MACHADO, C.G.: conception and design, analysis and interpretation of data, drafting the article; SILVA, G.Z.: conception and design, acquisition of data, analysis and interpretation of data, drafting the article, critical review of important intellectual content. All authors have read and approved the final version of the manuscript.

Conflicts of Interest: The authors declare no conflicts of interest.

Ethics Approval: Not applicable.

Acknowledgments: The authors would like to thank the funding for the realization of this study provided by the Brazilian agency CAPES (Coordenação de Aperfeiçoamento de Pessoal de Nível Superior - Brasil), Finance Code 001.

\section{References}

ANICESIO, E.C.A., et al. Dry mass, nutrient concentration and accumulation in safflower (Carthamus tinctorius L.) influenced by nitrogen and potassium fertilizations. Australian Journal of Crop Science. 2015, 9(6) 552-560.

ARAÚJO, F.S., et al. Adequação do teste de envelhecimento acelerado para avaliação do vigor de sementes de leucena. Agrária. 2017, 12(1) 92-97. http://dx.doi.org/10.5039/agraria.v12i1a5422

ÁVILA, M.R., et al. Testes de laboratório em sementes de canola e a correlação com a emergência das plântulas em campo. Revista Brasileira de Sementes. 2005, 27(1), 62-70. http://dx.doi.org/10.1590/S0101-31222005000100008

BAGHERI, H. and SAM-DALIRI, M. Effect of water stress on agronomic traits of spring safflower cultivars (Carthamus Tinctorius L.). Australian Journal of Basic and Applied Sciences. 2011, 5(12), 2621-2624.

BARBOSA, R.M., COSTA, D.S. and SA, M.E. Envelhecimento acelerado em sementes de alface. Ciência Rural. 2011, 41(11), $1899-1902$. http://dx.doi.org/10.1590/S0103-84782011005000138

BERGER, A.P.A., RANAL, M.A. and SANTANA, D.G. Variabilidade na dormência relativa dos diásporos de Lithraea molleoides (Vell.) Eng. Ciência Florestal. 2014, 24(2), 1-13. http://dx.doi.org/10.5902/1980509814570

BIDGOLY, R.O., et al. Effect of temperature and water potential on Carthamus tinctorius L. seed germination: Quantification of the cardinal temperatures and modeling using hydrothermal time. Industrial Crops \& Products. 2018, 113(3), 121-127.

https://dx.doi.org/10.1016/j.indcrop.2018.01.017

BRASIL, Ministério da Agricultura, Pecuária e Abastecimento: Instrução normativa no 45, de 17 de setembro de 2013, Brasília: MAPA, 2013.

BRASIL. Ministério da Agricultura, Pecuária e Abastecimento: Regras para Análise de Sementes. Brasília: Secretaria de Defesa Agropecuária, 2009.

CARVALHO, N.M. and NAKAGAWA, J. Sementes: ciência, tecnologia e produção. 5th ed. Jaboticabal: FUNEP, 2012.

COIMBRA, R.A., et al. Teste de germinação com acondicionamento dos rolos de papel em sacos plásticos visando a otimização dos resultados. Revista Brasileira de Sementes. 2007, 29(1), 92-97. https://doi.org/10.1590/S0101-31222007000100013

CORONADO, L.M. El cultivo Del cártamo (Carthamus tinctorius L.) en México. 1th ed. Ciudad Obregon: Instituto nacional de investigaciones forestales, agrícolas y pecuárias. 2010.

COSTA, C.J., TRZECIAK, M.B. and VILLELA, F.A. Potencial fisiológico de sementes de brássicas com ênfase no teste de envelhecimento acelerado. Horticultura Brasileira. 2008, 26(2), 144-148. http://dx.doi.org/10.1590/S0102-05362008000200003

DELOUCHE, J.C. and BASKIN, C.C., Accelerated aging techniques for predicting the relative storability of seed lots. Seed Science and Technology. 1973, 1, 427-452.

DEMIR, M. Conformity of vigor tests to determine the seed quality of safflower (Carthamus tinctorius L.) cultivars. Australian Journal of Crop Science. 2014, 8(3), 455-459.

EMONGOR, V. Safflower (Carthamus tinctorius L,) the underutilized and neglected crop: A review. Asian Journal of Plant Science. 2010, 9(6), 299-306. https://doi.org/10.3923/ajps.2010.299.306

FLAVIO. J.J.P. and PAULA, R.C. Testes de envelhecimento acelerado e de condutividade elétrica em sementes de Dictyoloma vandellianum A. Juss. Scientia Forestalis. 2010, 38(87), 391-399. 
FRANDOLOSO, D.C.L., et al. Qualidade de sementes de alface avaliada pelo teste de envelhecimento acelerado. Revista de Ciências Agrárias. 2017. 40(4), 703-713. http://dx.doi.org/10.19084/RCA17009

GALAVI, M., ROMROUDI, M. and TAVASSOLI, A. Effect of micronutrientes foliar application on yield and seed oil contente of safflower (Carthamus tinctorius). African Journal of Agricultural Research. 2012, 7(3), 482-486.

GAMA, G.F., et al. Substrates and duration for conducting the safflower seed germination test. Cientifica. 2019, 47(4) 426-433.

http://dx.doi.org/10.15361/1984-5529.2019v47n4p426-433

GIRARDI, L.B., et al. Envelhecimento acelerado em sementes de cártamo. Revista da FZVA. 2019, 19(1), 43-54.

GODAKAHRIZ, S.J., RASTEGAR, Z. and SHAHVERDIKANDI, M.A. Effect of seed aging on safflower (Carthamus tinctorius L.) seed vigor and germination parameters. International Research Journal of Applied and Basic Sciences. 2012, 3(3), 445-449.

GOMES FILHO, J.C., et al. Biodiesel production from Sterculia striata oil by ethyl transesterification method. Industrial Crops and Products. 2015, 74(15), 767-772. https://doi.org/10.1016/j.indcrop.2015.06.013

HONGYU, K., SANDANIELO, V.L.M. and OLIVEIRA JUNIOR, G.J. Análise de componentes principais: Resumo teórico, aplicação e interpretação. Engineering and Science. 2016, 5(1), 83-90. http://dx.doi.org/10.18607/ES201653398

ISTA. International Seed Testing Association. Seed Vigour Testing. International Rules for Seed Testing, Zurich: ISTA, 2014.

JIANHUA, Z. and McDONALD, M.B. The saturated salt accelerated aging test for small-seeded crops. Seed Science and Technology. 1997, 25(1), 123-131.

KAYA, M.D., et al. Prediction of viability and emergence capacity of safflower seed lots. The Journal of Animal \& Plant Sciences. 2019, 29(3), 714-720.

KHAVARI, F., GHADERI-FAR, F. and SOLTANI, E., Laboratory tests for predicting seedling emergence of safflower (Carthamus tinctorius L.) cultivars. Seed Technology. 2009, 31(2), 189-193.

KIZIL, S., et al. Comprehensive study on Safflower (Carthamus tinctorius L.) in semi-arid conditions. Biotechnology \& Biotechnological Equipment. 2008, 22(4), 947-953. https://doi.org/10.1080/13102818.2008.10817585

LENZ, N.B.G., et al. Sowing Depth on Emergence of Different Safflower Genotypes (Carthamus tinctorius L.). Journal of Agricultural Science. 2017, 9(12), 135-151. http://dx.doi.org/10.5539/jas.v9n12p135

LOPES, C.A., et al. Importance of amylases for physiological quality in maize seeds. Biotemas. 2017, 30(3), 1-7.

MACHADO, C.G., et al. Accelerated aging test for forage pea seeds. Semina: Ciências Agrárias. 2019, 40(5), $1819-1828$. http://dx.doi.org/10.5433/1679-0359.2019v40n5p1819

MAGUIRE, J.D. Speed of germination-aid in selection and evaluation for seedling emergence and vigor. Crop Science. 1962, 2(2), $176-177$. https://doi.org/10.2135/cropsci1962.0011183X000200020033x

MARCOS FILHO, J. Seed vigor testing: an overview of the past, present and future perspective. Scientia agrícola. 2015, 72(4), 363-374. https://doi.org/10.1590/0103-9016-2015-0007

MARCOS FILHO, J. Seed physiology of cultivated plant. 1st ed. Londrina: ABRATES, 2016.

MARINHO, J.L., et al. Evaluation of vigor and tolerance of sweet corn seeds under hypoxia. Journal of Seed Science. 2019, 41(2), 180-186. http://dx.doi.org/10.1590/2317-1545v41n2209568

MARTINS, A.B.N., et al. Accelerated aging test in amaranth (Amaranthus cruentus L.) seeds. Australian Journal of Crop Science. 2018, 12(3), 444-448.

MARTINS, A.B.N., et al. Analysis of seed quality: a nonstop envolving activity. African Journal of Agricultural Research. 2014, 9(49), 3549-3554.

MCDONALD JUNIOR, M.B. and PHANEENDRANATH, B.R. A modified accelerated aging seed vigor test for soybeans. Journal of Seed Technology. $1978,3(1), 27-37$.

MENEZES, V.O., et al. Envelhecimento acelerado em sementes de Zinnia elegans Jacq. colhidas em diferentes épocas. Revista Brasileira de Sementes. 2008, 30(3), 39-47. http://dx.doi.org/10.1590/S0101-31222008000300006

NAKAGAWA, J., 1994. Testes de vigor baseados na avaliação das plântulas. In: VIEIRA, R.D. and CARVALHO, N.M. (Eds.). Testes de vigor em sementes. Jaboticabal: FUNEP, pp. 49-85.

OVALLES, F.A. and COLLINS, M.E. Variability of northwest Florida soils by principal component of analysis. Soil Science Society of American Journal. 1988, 52(5), 1430-1435. https://doi.org/10.2136/sssaj1988.03615995005200050042x

RADKE, A.K., et al. Alternativas metodológicas do teste de envelhecimento acelerado em sementes de coentro. Ciência Rural. 2016, 46(1), 9599. http://dx.doi.org/10.1590/0103-8478cr20140188

R CORE TEAM. R: a language and environment for statistical computing. Vienna: R Foundation for Statistical Computing, 2019. Available from: http://www.R-project.org/ 
RIBEIRO, M.C.C., MARQUES, B.M. and AMARRO FILHO, J. Efeito da salinidade na germinação de sementes de quatro cultivares de girassol (Helianthus annuus L.). Revista Brasileira de Sementes. 2001, 23(1), 281-284. http://dx.doi.org/10.17801/0101-3122/rbs.v23n1p281-284

ROCHA, C.R.M., SILVA, V.N. and CICERO, S.M. Avaliação do vigor de sementes de girassol por meio de análise de imagens de plântulas. Ciência Rural. 2015. 45(6), 970-976. http://dx.doi.org/10.1590/0103-8478cr20131455

SANTANA, D.G. and RANAL, M.A. Análise da germinação: um enfoque estatístico. 1st ed. Brasília: Editora Universidade de Brasília, 2004.

SINGH, V. and NIMBKAR, N., 2016. Safflower. In: GUPTA, S.K. (Eds.). Breeding Oilseed Crops for Sustainable Production. Jammu: Academic Press, pp. 147-165.

SOLEYMANI, A. Safflower (Carthamus tinctorius L.) seed vigor tests for the prediction of field emergence. Industrial Crops and Product. 2019, 131, 378-386. http://dx.doi.org/10.1016/i.indcrop.2017.03.022

TUNES, L.M., et al. Accelerated aging to assess parsley seed vigor. Horticultura Brasileira. 2013, 31(3), 457-460. http://dx.doi.org/10.1590/S0102-05362013000300018

YAO, Y., et al. Structural elucidation and immune-enhancing activity of an arabinogalactan from flowers of Carthamus tinctorius L. Carbohydrate Polymers. 2018, 202, 134-142. https://doi.org/10.1016/i.carbpol.2018.08.098

Received: 26 April 2020 | Accepted: 12 October 2020 | Published: 16 February 2022

This is an Open Access article distributed under the terms of the Creative Commons Attribution License, which permits unrestricted use, distribution, and reproduction in any medium, provided the original work is properly cited. 